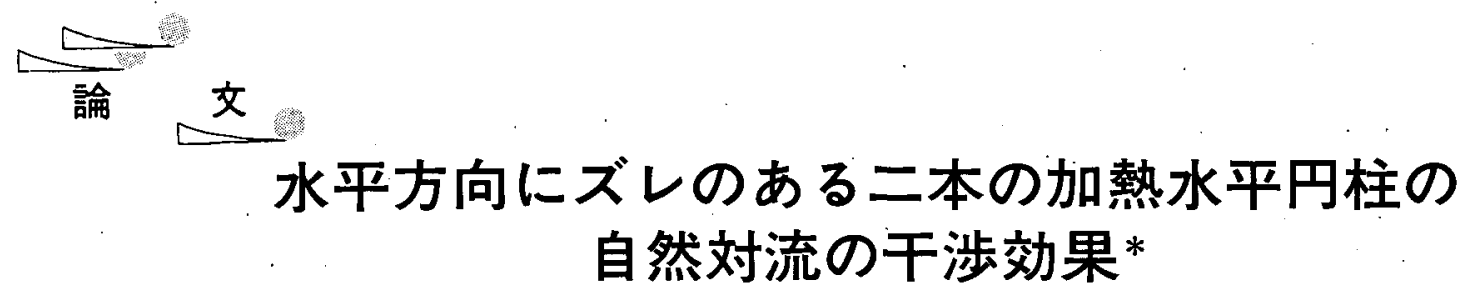

亀岡 利行**, 岡田 裕紀***, 久保 真治 $^{\dagger}$, 秋野 詔夫 ${ }^{\dagger \dagger}$, 田中. 周 ${ }^{\dagger}$, 高瀬 和之 ${ }^{\dagger}$

\title{
Interaction of Natural Convection between Two Heated Horizontal Cylinders Installed Alternately
}

\author{
Toshiyuki Kameoka, Yuuki Okada, Shinji Kubo, \\ Norio Akino, Amane Tanaka and Kazuyuki TaKase
}

\begin{abstract}
An experimental study was carried out to investigate the natural convection around two heated horizontal cylinders set in a rectangular enclosure. The heat transfer coefficient of the cylinders is calculated from heat flux, surface temperature and fluid temperature obtained by thermocouples. Temperature distributions and flow appearance were visualized by the liquid-crystal suspension method. The thermo-fluid behavior was characterized by the stratification and the thermal plumes from the heated cylinders. By means of accomplishment in both heat transfer coefficient measurement and the visualization, the varying of heat transfer observed was explained by the interaction between thermal plume from lower cylinder and the boundary layer around the upper cylinder.
\end{abstract}

Key words: Natural convection, Horizontal cylinder, Enclosure, Thermal stratification, Visualization, Interaction

\section{1. 緒 言}

容器内に設置された複数の加熱体まわりの自然対流は, 形成される温度成層や熱的相互干涉等に起因して複雑な 伝熱現象を生じさせる。これは, 熱交換器, 蓄熱槽等の 多くの伝熱・熱利用機器の詳細な特性評価に共通する問 題である．例えば，加熱水平円柱まわりの自然刘流は， 無限空間に設置された場合について極めて多くの実験・ 解析的研究が行われているが，現実の機器のごとく容器 中に多数の伝熱管が設置される場合に適用でさるか否か 検討を要寸る。そこで, 我々は矩形容器内に設置された 二本の加熱水平円柱まわりの自然対流伝熱現象を取り上 げ，一連の実験的，解析的研究を進めてきた。

前報”では, 垂直に上下二本の円柱を並べて，その中心 軸間隔を 2 直径あけた配置条件において, 熱伝達の測定 を行うと共に感温液晶懸濁法を用いて温度場と流れ場の 可視化を行った. 加熱円柱より立ち昇るプリュームと容

* 原稿受付 1997 年 3 月 14 日

** 正会員 東京電機大学

**** 東芝

十 日本原子力研究所

† 正会員 日本原子力研究所
器内に形成される循環流及び温度成層が干渉して複雑な 挙動が生じることを示し，それらと熱伝達率との関連を 明らかにした。また，熱伝達率の評価に用いる代表周囲 流体温度の取り方を検討し, 各円柱の軸心より 1 直径上 方の位置の流体温度を取るとよいことを明らかにした。

本報でば熱伝達測定と可視化を併用した実験的研究を 行い，上下円柱の位置関係に水平方向のズレ（オフセッ 卜）がある場合について，上円柱の熱伝達に特異な增減 が生じることを見出し，それが下の加熱円柱から発生し たプリューム（下プリューム）の上円柱付近の挙動に対 応して生じていることを述べる。

\section{2. 実験装置および方法}

Fig. 1 に実験装置の概要を示す. 作動流体（シリコン オイルと感温液晶を混ぜたもの）を満たした容器に円柱 を設置して，それを冷却用の水を満たした外側容器に入 れ込んである。この外側容器には恒温水を循環させてお り, 内側容器壁面を等温に保つことができる。作動流体 の代表温度, 円柱壁面温度や発熱量はコンピュー夕を用 いて自動計測した．また，容器の側部からスリット光を 照射して直交する方向から可視化観祭を行った。 


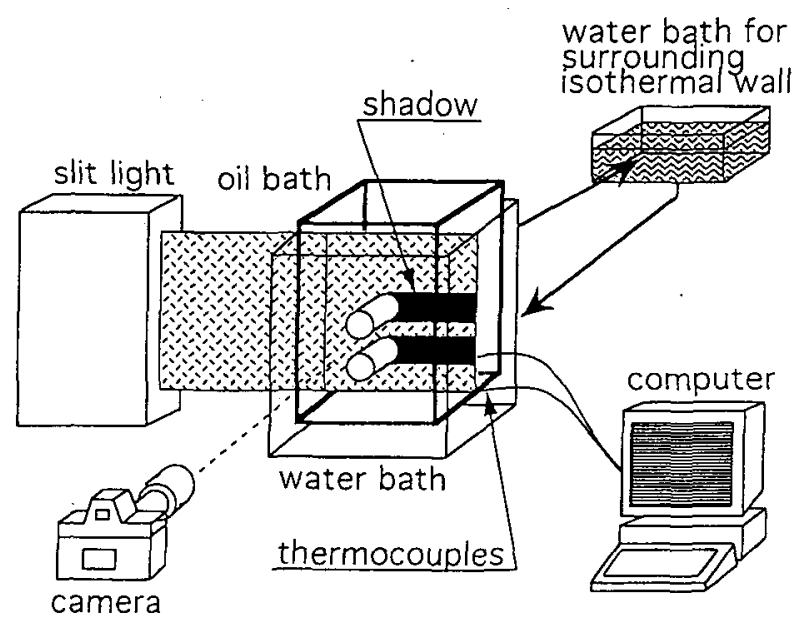

Fig. 1 System setup.
Fig. 2 に本実験で使用した実験装置を示す。(a)で示す ように透明アクリル樹脂製矩形容器内に 2 本のテスト円 柱を水平に設置した. 容器幅方向中央から $50 \mathrm{~mm}$ 右寄 りに設置されたテスト円柱は(b)に示すように直径 24 $\mathrm{mm}$, 厚さ $4.5 \mathrm{~mm}$, 長さ $122 \mathrm{~mm}$ の銅パイプであり, 内 部の電気ヒータで加熱する，加熱面温度を一様にするた めに，厚肉の銅パイプを用いた。 円柱表面を溝加工して， 二本の壁面温度測定用 JIS-K 型熱電対をハンダで埋め 込み表面を仕上げてある.この熱電対の取り付け位置は， 円柱の中心軸を通る水平線上で円柱の左右の表面である. この二点の平均值を円柱壁面温度とした。試験空間であ る矩形容器 $\left(300 \times 300 \times 500 \mathrm{~mm}^{3}\right)$ の上面は二重の蓋に て断熱条件とし，残りの 5 壁面は恒温水を流して一定壁 温とした。作動流体はシリコンオイル（温度 $298.2 \mathrm{~K} に$

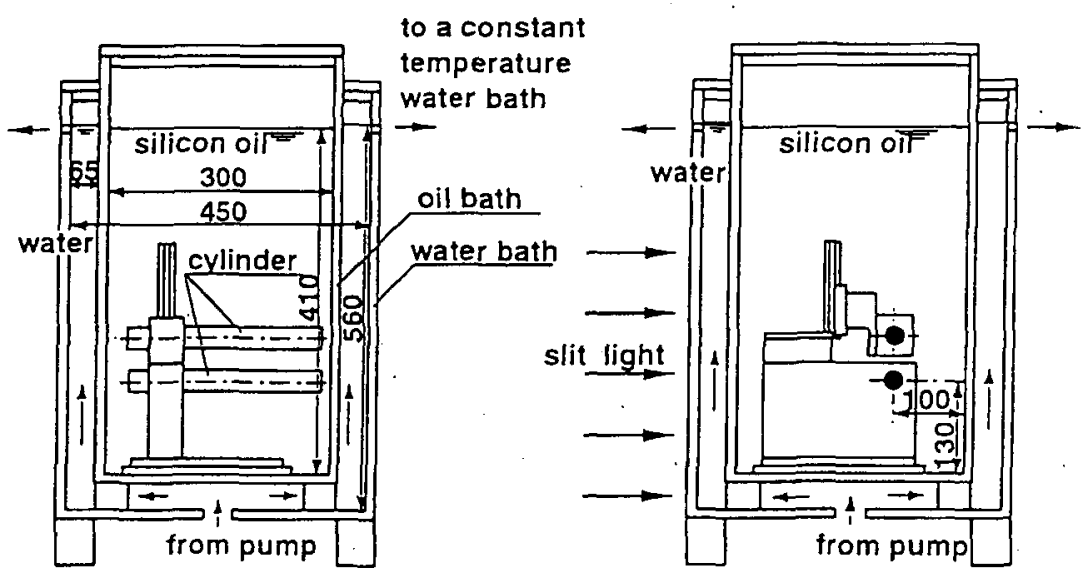

(a) Schematic of experimental apparatus

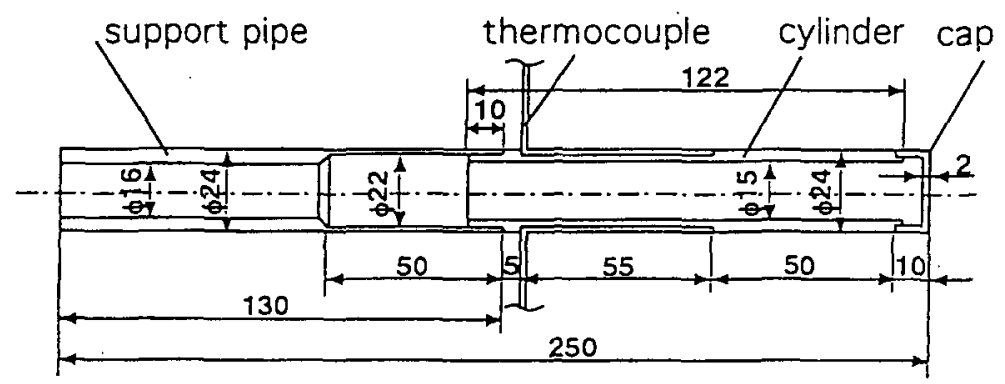

(b) Detail of test cylinder

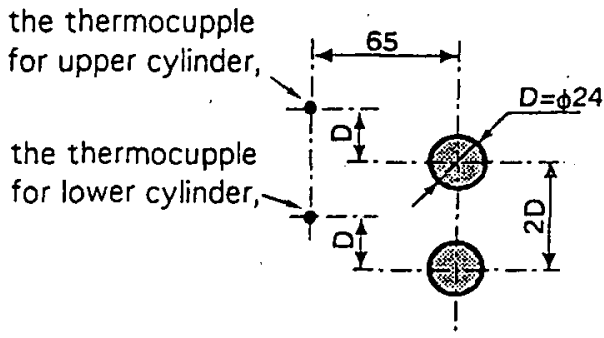

without offset $S / D=0$

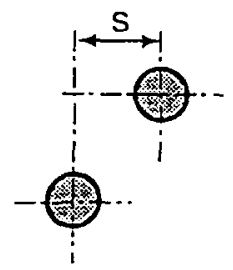

with the offset ratio of S/D

(c) The positions of thermocouples

Fig. 2 Experimental apparatus. 
おいてプラントル数 197 , 密度 $9.993 \times 10^{2} \mathrm{~kg} / \mathrm{m}^{3}$, 比熱 $1.578 \times 10^{3} \mathrm{~J} /(\mathrm{kg} \cdot \mathrm{K})$, 熱伝導率 $1.237 \times 10^{-1} \mathrm{~W} /(\mathrm{m} \cdot$ $\mathrm{K})$, 粘性率 $1.545 \times 10^{-2} \mathrm{~Pa} \cdot \mathrm{s}$, 体膨張率は $8.533 \times$ $\left.10^{-4} 1 / \mathrm{K}\right)$ であり, 容器に $410 \mathrm{~mm}$ の深さまで満たし た.

オフセットのない場合, Fig. 2 (c)の左図に示すように, 各円柱中心から 1 直径上方に設置した熱電対によって各 円柱の代表周囲流体温度を測定した。オフセットのある 場合には，熱電対の位置は変更せずに，Fig. 2 (c)右図に 示すように鉛直配置から上円柱を距離 $S$ だけ水平移動 させて両円柱間にオフセットを与えた. $S$ を円柱直径 $D$ で割った $S / D$ を無次元オフセット量とした。なお，上下 円柱の垂直方向中心間距離 $P$ は 2 直径 $(48 \mathrm{~mm})$ に保っ た.

円柱壁面温度, 周囲流体温度, 七ー夕の電流，電圧を 5 分間隔で測定した。これらの測定と可視化観察を加熱 開始から 400 分経過するまで行った。

作動流体中には温度分布を可視化観察するために, 温 度で色が変化する感温液晶（日本カプセルプロダクツ社 製, W-30 型, 呈色領域: $24.8 \sim 29^{\circ} \mathrm{C}$ )を重量濃度比 0.02 wt\%で混入懸濁した。

\section{3. 実験結果および考察}

上円柱のみ加熱した実験と，オフセット量 $S / D$ を 0 $\leqq S / D \leqq 5 / 4 の$ 範国にて 11 通りに変化させた実験を 行った。 円柱は電気七一夕にて等熱流束で加熱した。発 熱量は上下円柱ともに $6 \mathrm{~W}$ である。この条件ではレイ リー数 $R a=\operatorname{Pr} \cdot D^{3} g \beta \Delta T / \nu^{2}$ は $7.5 \times 10^{5}$ 程度である. ここで, Pr: プラントル数, $D$ : 円柱直径, $g$ : 重力加速 度, $\beta$ : 体膨張率, $\Delta T$ : 境膜温度差, $\nu$ : 動粘性率であ る.

\section{1 温度とヌセルト数の経時変化}

以下に特徴的な 4 つのオフセットの結果を示す。まず， 円柱の壁面温度の経時変化を Fig. 3 に示す.

(a)は $S / D=0$ (上下円柱を鉛直に配置) の場合であ る.下円柱壁温は 12 分までに急速に上昇して，その後 ゆっくりと上昇した．これに対して，上円柱壁温は 12 分 までは下円柱とともに上昇しているが，その後下円柱よ りもさらに上昇して 22 分で温度がピークを示した。その 後, 上円柱壁温は低下して 37 分で下円柱壁温とほ涩同じ になったささらに加熱を続けると上円柱壁温は下円柱壁 温よりも上昇した。

(b)は $S / D=1 / 12$ に配置した場合である.上円柱壁温 は加熱開始から 22 分まで下円柱壁温より低かったが, 27 分で急に上回った。さらに, 80 分以降上円柱壁温は下円 柱より相対的に上昇し, 130 分でピークを示した後,下円 柱より高い温度のままほ潘定常状態に達した。

(c)はS $/ D=1 / 2$ 亿配置した場合である。加熱開始から 37 分を越えるまで, 上円柱壁温は下円柱壁温より低加 た.40分から80分にかけて上円柱壁温が上昇した. 100
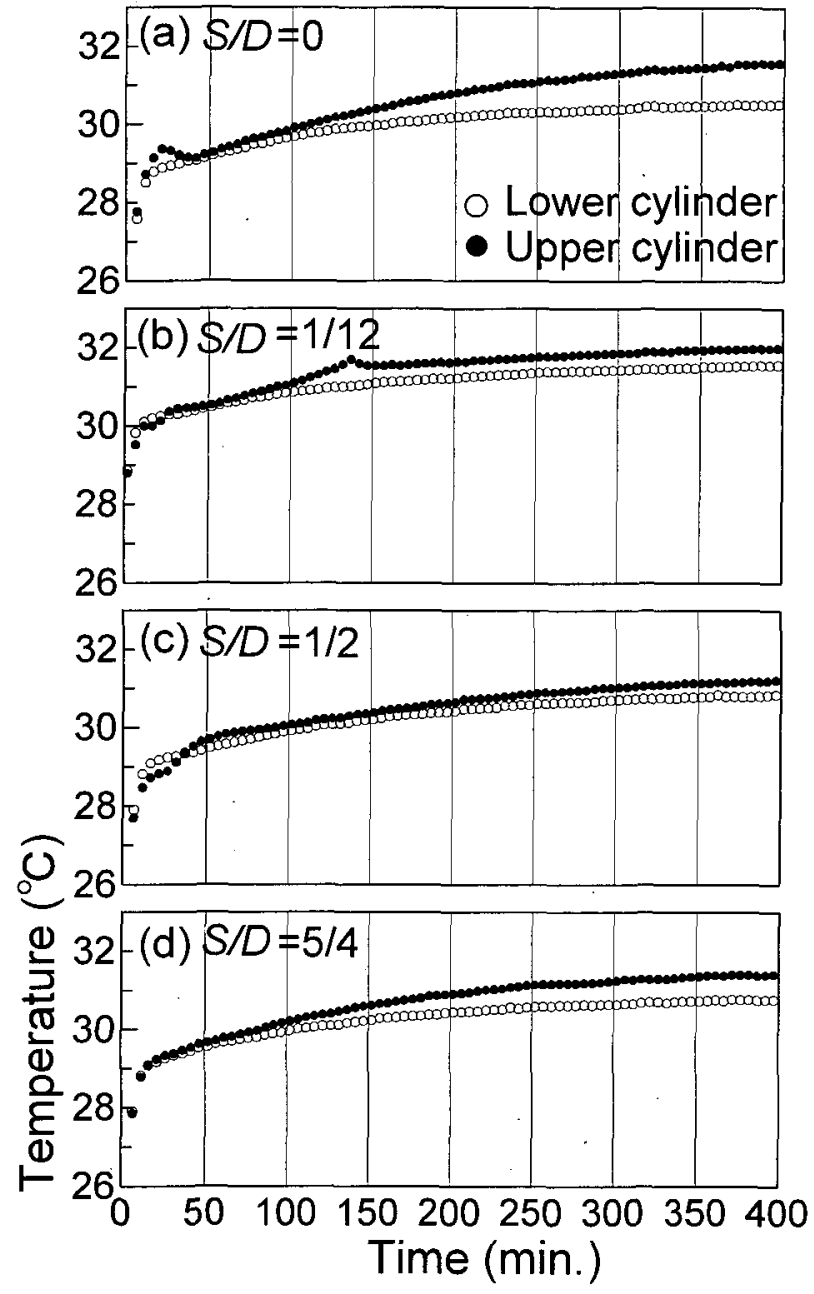

Fig. 3 Time variation for temperature of two cylinders.

分前後に上下円柱壁温の差が小さくなったが，その後， 徐々に開いていった。

(d)は $S / D=5 / 4$ に配置した場合である.加熱開始から 上下円柱がほ涩同じように上昇していき，徐々に上円柱 の方が高くなっていった。

次に, ヌセルト数 $N u=h D / \lambda$ の経時变化を Fig. 4 に 示す.ここで, $h$ : 熱伝達率 $=q / \Delta T, q$ : 熱流束（円柱内 ヒー夕発熱量から求める), 六: 熱伝導率である. 図中に示 した $N u_{s}$ は上円柱のみを単一加熱した場合のヌセルト 数である.

(a) $S / D=0$ に配置した場合である.上円柱ヌセルト 数 $N u_{u}$ は 17 分で極小値をとった後, $N u_{s}$ を上回る値ま で急增するが，その後ゆっくりと減少し，177 分以降は $N u_{s}$ を下回った. 下円柱ヌセルト数 $N u_{\text {乙 }}$ は加熱開始初期 を除き，緩やかな増大傾向を示し，最終的に $N u_{s}$ より大 となった。

(b) $S / D=1 / 12$ に配置した場合である. $N u_{u}$ は 32 分で一度極小值を示した後に上昇し，60 分で $N u_{s}$ に接 近した後に再び低下して，137 分で 2 度目の極小值と なった. $N u_{l}$ は2 27 分で極小值となり，その後ゆっくり上 昇した。250分前後からは $N u_{u}$ と $N u_{l}$ は活㹬同じ值に 

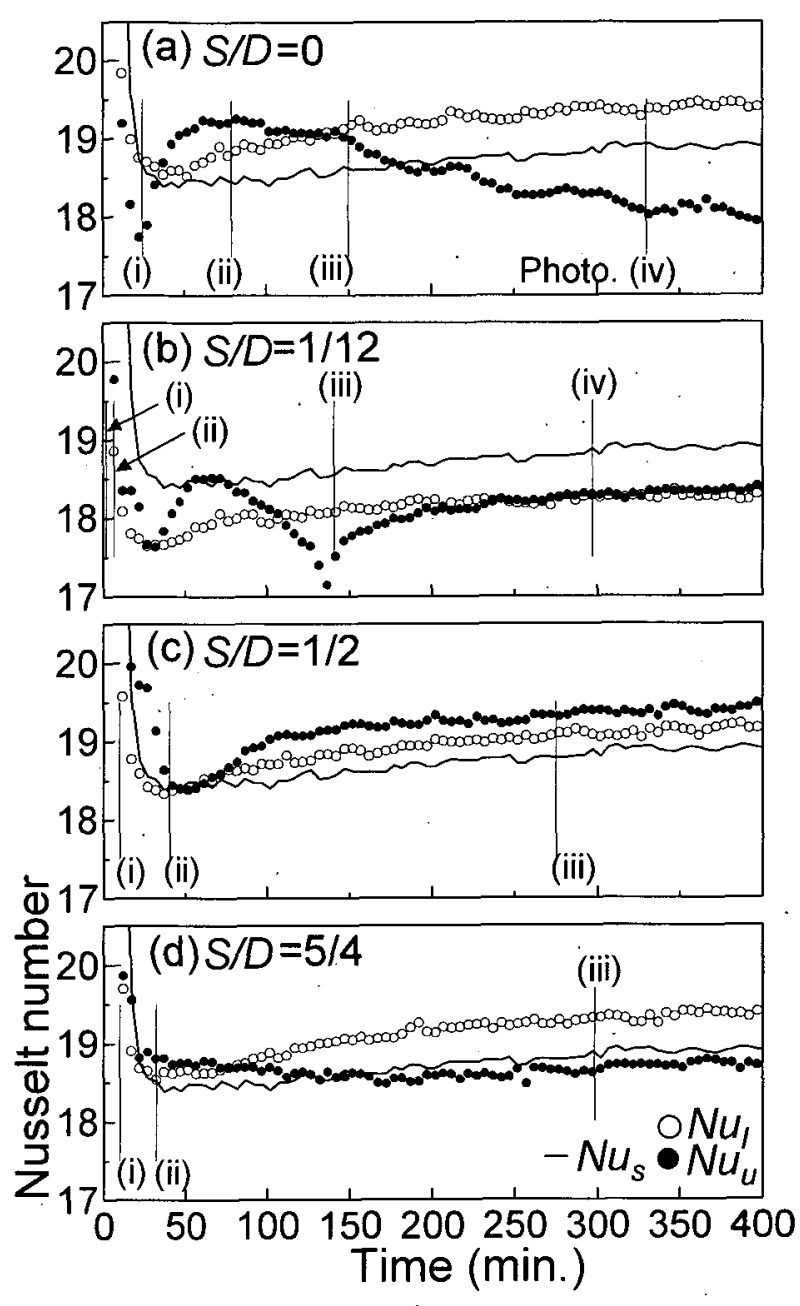

Fig. 4 Time variation for Nusselt number of two cylinders.

なった。

(c)は $S / D=1 / 2$ に配置した場合である. $N u$ は加熱 開始後 52 分で極小值となり，その後上昇して, 397 分で は $N u_{s}$ より $3 \%$ 高くなった．また，Nulは，37分で極小 值となり，その後ゆっくり上昇して，397 分では $N u_{u}$ よ りも低くなった。

(d)は $S / D=5 / 4$ に配置した場合である.Nuいは加熱 開始後 72 分まで $N u$ をを上回っている.その後, 極小值を 示すことなく 200 分前後までゆっくりと低下し，再び上 昇して，397 分で $N u_{s}$ とほほ同じになった．Nulは，32 分でゆっくりと極小值となり，その後ゆっくり上昇した。 397 分では $N u_{u}$ よりも高くなった。

\section{2 上円柱のヌセルト数とオフセット量の関係}

ヌセルト数の経時変化は下円柱はゆっくりと単純なの に対して，上円柱には複雑な挙動が観測された。 そこで, 上円柱のヌセルト数に注目した. Fig. 4 (b)に示したオフ セット量 $S / D=1 / 12$ と Fig. 4 (d)の $S / D=5 / 4$ を比較 すれば顕著なように，上円柱のヌセルト数の経時変化が 比較的短時間（10 分オーダー）に堌減するものと, 緩や かに変化するものがあり，オフセットが $1 / 2$ より大きい

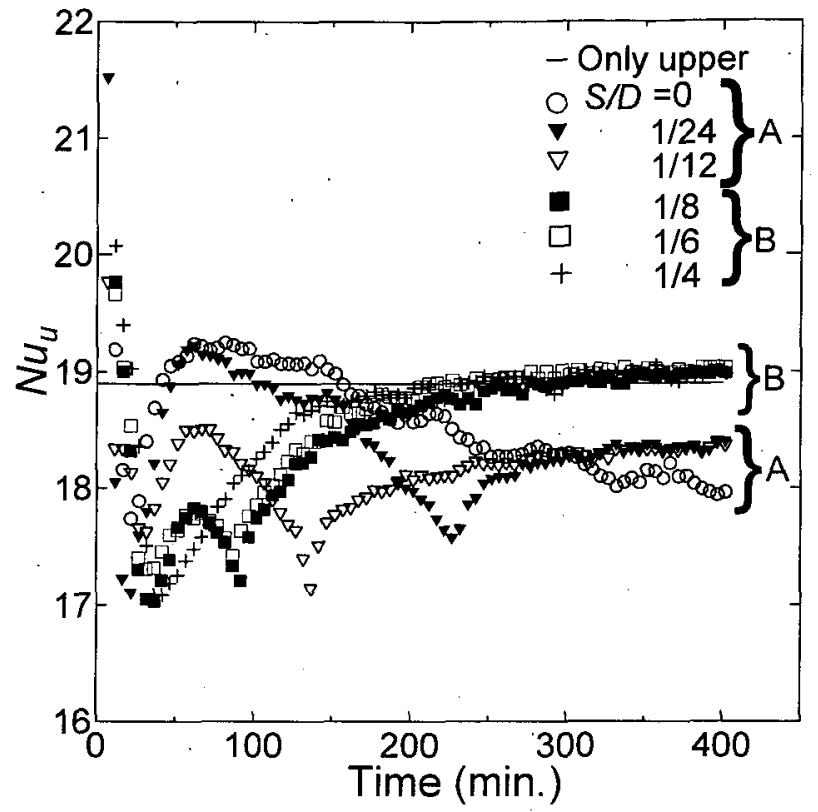

Fig. 5 Time variation for $N u_{u}$ with offset ratio $0 \leq S / D \leq 1 / 4$

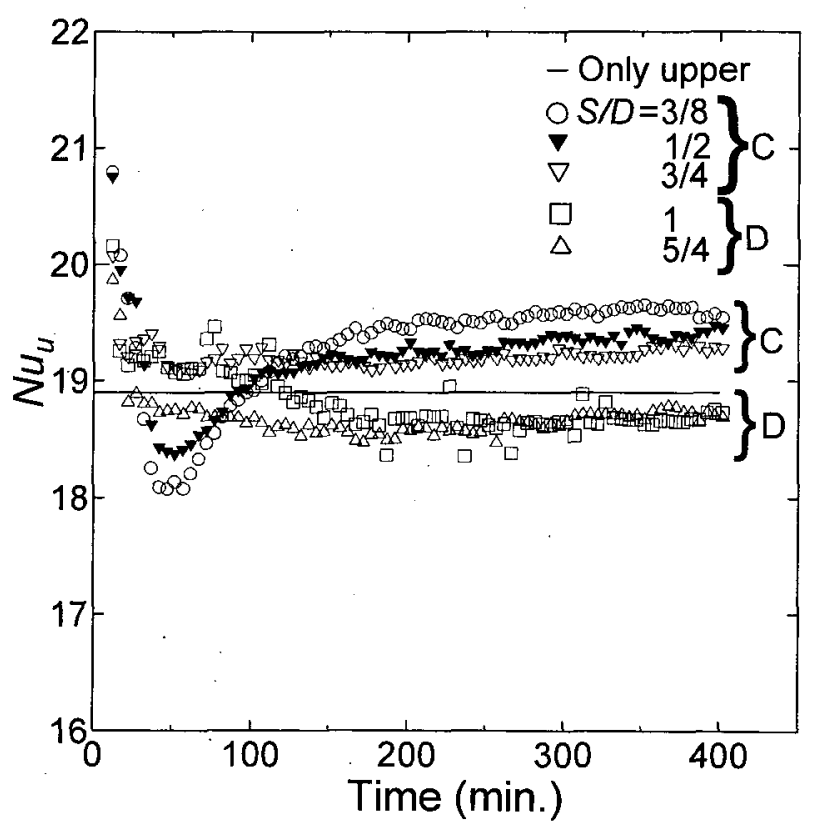

Fig. 6 Time variation for $N u_{u}$ with offset ratio $3 / 8 \leq S / D \leq 5 / 4$

条件では単純であった．まず，上円柱のヌセルト数が急 に增減する場合である，オフセット $0 \leqq S / D \leqq 1 / 4$ にお ける $\mathrm{Nu}_{u}$ の経時変化を Fig. 5 に示す。図中の直線法長時 間経過後の上円柱単独加熱時のヌセルト数 $N u_{s}$ の值で ある. $0 \leqq S / D \leqq 1 / 4$ では，いずれの場合も一回あるいは 二回ほど熱伝達の急な増減が生じた。ままた加熱開始から 長時間経過した 400 分の值は, $S / D=0,1 / 24,1 / 12$ で は $N u_{s}$ と此べると，低い值となっている． $S / D=1 / 8$, 1/6, 1/4 は $N u_{s}$ とほほ同等であった。次に, Fig. 6 に, 上円柱のヌセルト数が単純に変化する場合である， $3 / 8$ 
$\leqq S / D \leqq 5 / 4$ における $N u_{u}$ の経時変化を示す. $S / D=$ $3 / 8,1 / 2$ は加熱後ごく初期に極小值を示している. $S / D$ $=3 / 4$ 以上だと顕著な極小值はない. 加熱開始後長時間 経過した 400 分の $N u_{u}$ は, $\mathrm{S} / \mathrm{D}=3 / 8,1 / 2,3 / 4$ では $N u_{\mathrm{s}}$ より高く, $\mathrm{S} / \mathrm{D}=1,5 / 4$ では $N u_{s}$ とほ涩同等である。

栗山ら ${ }^{3)}$ は垂直に並べた二本の水平円柱の自然対流の 上円柱の熱伝達率について，下部円柱から到達する高温 の浮力流が上部円柱を包み込むことによる抑制効果とな がれの重畳による促進効果の兼站合いに依存する現象だ としている. 本実験結果では, オフセット量の増加に従 い, 長時間経過後の $N u_{u}$ は $N u_{s}$ に比べて小 (A), 同等 $(\mathrm{B})$, 大 $(\mathrm{C})$, 同等 $(\mathrm{D})$ のように変化 $(\mathrm{A}, \mathrm{B}, \mathrm{C}, \mathrm{D}$ は Figs. 5，6 中の記号）した. 従って, 本研究においても 上円柱の熱伝達に対する下プリュームの効果には, 熱伝 達を促進するものと抑制するものとがあることは同様で あった。

加熱開始後長時間経った場合の上円柱熱伝達とオフ セット量の関係は，次のように解釈することができる。 層流域での垂直平板自然対流の速度境界層々温度境界層 の厚さを比較すると, 本実験で用いた $P r=200$ 程度の 流体では, 速度境界層が十数倍程度厚い: 円柱から立ち 昇るサーマルプリュームでも, 同程度のオーダーの構造 であると考えられるので，下プリュームが上円柱の境界 層に与える影響は，温度的にも速度的にも接触している 場合, 速度的に接触している場合, 接触していない場合 に分けることができる.ささて, 長時間経つと下プリュー ムは上円柱の側方を通過する，オフセット量と長時間経 過後の下プリュームと上円柱間の距離はほほ比例してい ると考えられる.オフセットが小さいと高温の下プ リュームが上円柱を取り囲み熱伝澾は抑制される。オフ セットの増加とともに下プリュームと円柱の距離も次第 に離れ，流れの重畺による促進と包み込みによる抑制が 同程度になったところで，上円柱熱伝達は単独円柱のそ れと同程度になる。ささらにオフセットが大きくなると促 進効果が勝り単独円柱の熱伝達より増加し, 十分オフ セットが大きいと二本の円柱は干涉しなくなり，単独円 柱のそれと同程度になる。

\section{3 可視化観察}

上述の熱伝達測定と同時に円柱付近の温度分布を可視 化観察（Figs. 7〜10）を行った. 使用した感温液晶の色 は, 温度の上昇とともに, 黒, 赤み帯びたオレンジ, 黄 土色, 緑, 青と変化する. 従って, 写真の温度分布は, 黒と赤系の色が低温域, 青系の色が高温域に対応してい る.また，露光時間が 30 秒なので速度の速い領域である 速度境界層は円柱に沿った軌跡の集合として観察できる。

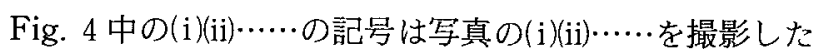
時刻に対応している.

可視化によって，下プリュームの進路が上円柱の左右 へ振れて変化する挙動が観察できた。この挙動の有無は オフセット量の大小に関係しており，2つのグループに
分けられた. $0 \leqq S / D \leqq 1 / 4$ では,下プリュームが実験中 進路を変更した。また， $3 / 8 \leqq S / D$ では，下プリューム は常に上円柱の左側を上昇し, 実験中に進路を変更しな かった. Fig. 5 と Fig. 6 亿示した上円柱の熱伝達の増減 は，下プリュームが上円柱から離れている，上円柱を取 り囲んでいる,などのプリュームの進路と対応が見られ た。稲垣ら ${ }^{2)}$ は円柱の伝熱面の温度分布の可視化を行い, 干渉を伴う自然対流熱伝達は自然対流の摇動と自然対流 同士の干涉（加速効果および周囲の低温流体の巻き込み 現象）とが密接に関連していると述べている. 本研究に おいても，下プリュームが上円柱の境界層に干渉するた めに熱伝達の変化が起こると考えられる.

以下に Fig. 4 に対応した 4 つの例を挙げる。まず，下 プリュームが上円柱の左右に進路を変える場合のうち二 つの可視化結果を示す. Fig. 7 は $S / D=0$ に配置した場 合の可視化写真である.下プリュームは加熱開始直後鉛 直に上昇して上円柱を包むようになうた。その後, 徐久 に変化し(i)に示すように上円柱の右側をまわって上昇し た (24 分)。この時, Fig.4(a)の上円柱ヌセルト数は極小 值を取っている．下プリュームは上円柱壁面に沿うよう に流れている. (ii)梳加熱開始後 79 分の状態である. 上円 柱の向かって右肩部分の色分布を見てみると, 壁面上に は高温の温度境界層（青, 黄）がある。その外側に黒い 層（低温）が存在し, さらに外側には赤や黄の層が観察 される.これらより，下プリュームがその周囲の流体(低 温）を巻き込みながら，上円柱壁面に到達していること が分かる。このため下プリュームと上円柱壁面との間に 低温の層ができ，上円柱壁面に沿って流れる高温流体が 排除され，代わりに低温の周囲流体が壁面近傍に流入し て流れが重畳するため, 上円柱まわりの熱伝達が促進さ れている. (iii) は加熱開始後 150 分の状態である. 時間経 過とともに下プリュームは上円柱壁面に徐々に接近して いる. (iv)は加熱開始後 330 分の状態である. 下プリュー ムと上円柱壁面の間には低温層が見られなくなっており， 両者は熱的に接しているので上円柱の熱伝達が低下して いる.

Fig. 8 は $S / D=1 / 12$ 亿配置した場合の可視化例であ る. (i)に示すように, 加熱開始直後の下プリューム鉛直 に上昇し，上円柱が右方にオフセットしているため上円 柱の左側を流れた。しかし, その 5 分後, 下プリューム は上円柱の下方を横切り上円柱の右側に進路を変えた(ii)。 その後, プリュームは(iii)の状態を経て左側に移り(iv), 以 降は 400 分経過後も右側に戻らなかった. 上円柱が下プ リュームに包まれた状態(iii)とほほ同時刻には, Fig. 3(b) に示すように円柱の温度が上昇し，Fig. 4 (b)に示すよう にNưが極小值をとった。

次に，下プリュームが上円柱の左右に進路を変えない 例のうち二つの可視化結果を示す. Fig. 9 は $S / D=1 / 2$ に配置した場合の可視化例である。(i)は加熱開始後 10 分 の状態である.下プリュームは下円柱から鉛直上昇し, 


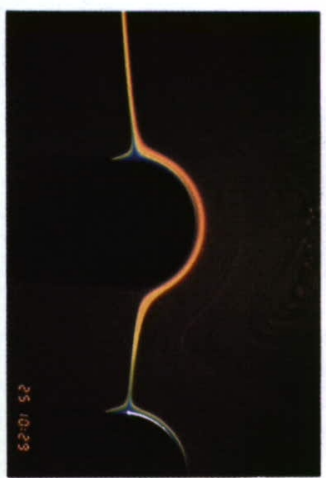

(i) $24 \mathrm{~min}$

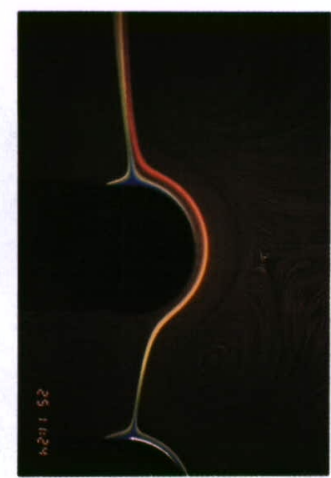

(ii) $79 \mathrm{~min}$.

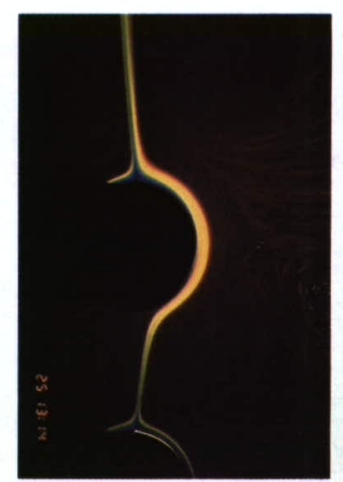

(iii) $150 \mathrm{~min}$

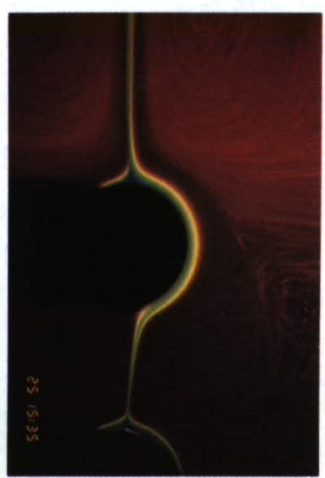

(iv) $330 \mathrm{~min}$.

Fig. 7 The visualized plume at the condition of two cylinders heated with the offset ratio of $S / D=0$ (ISO $100,30 \mathrm{sec}, \mathrm{f} 5.6)$.

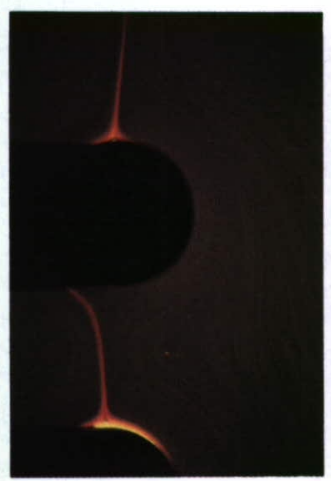

(i) $2 \mathrm{~min}$.

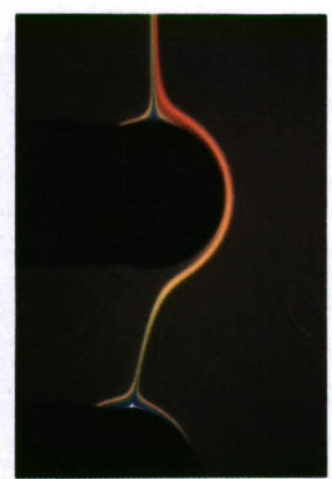

(ii) $7 \mathrm{~min}$.

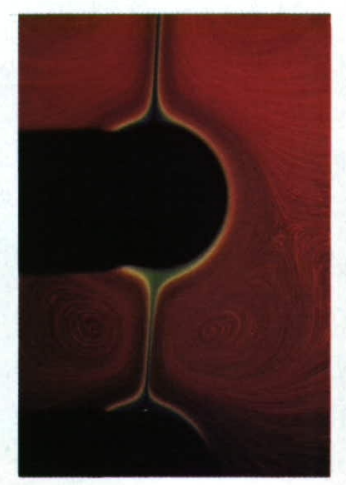

(iii) $141 \mathrm{~min}$.

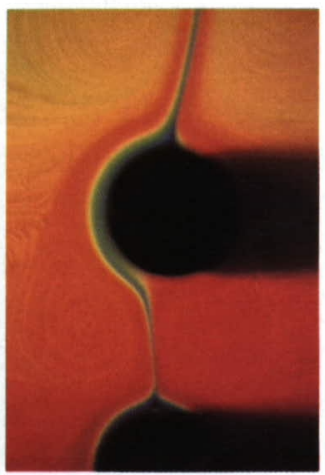

(iv) $297 \mathrm{~min}$.

Fig. 8 The visualized plume at the condition of two cylinders heated with the offset ratio of $S / D=1 / 12 \quad$ (ISO $100,30 \mathrm{sec}$, f 5.6).

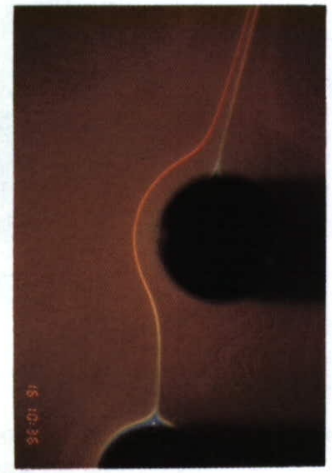

(i) $10 \mathrm{~min}$

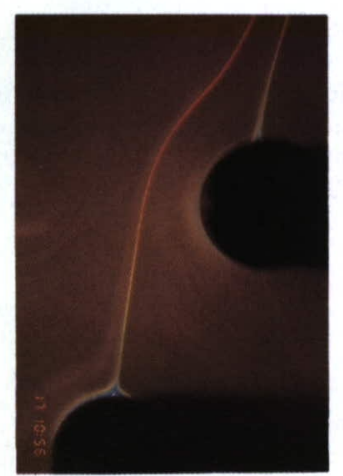

(i) $10 \mathrm{~min}$.

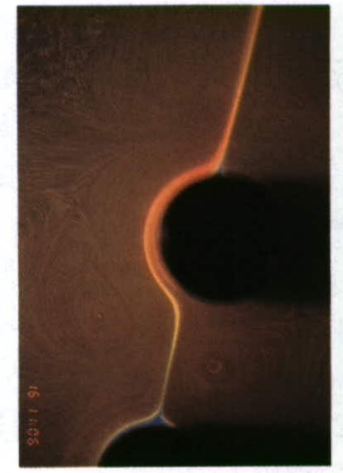

(ii) $40 \mathrm{~min}$.

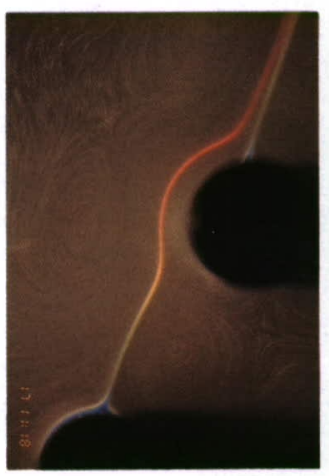

(ii) $32 \mathrm{~min}$.

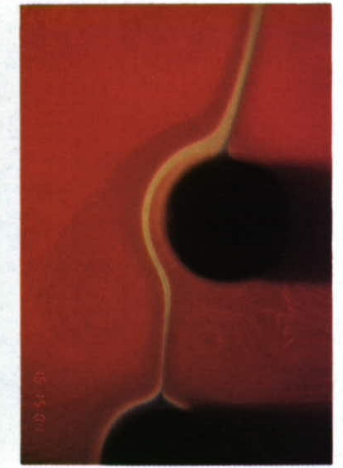

(iii) $275 \mathrm{~min}$.

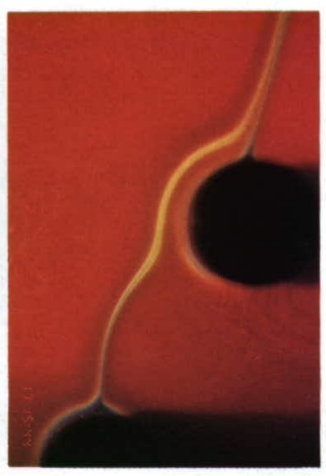

(iii) $298 \mathrm{~min}$.
Fig. 9 The visualized plume at the condition of two cylinders heated with the offset ratio of $S / D=1 / 2($ ISO $100,30 \mathrm{sec}, \mathrm{f} 5.6)$.

Fig. 10 The visualized plume at the condition of two cylinders heated with the offset ratio of $S / D=5 / 4$ (ISO 100 , $30 \mathrm{sec}$, f 5.6). 
上円柱に沿って流れているが，壁面との距離は約（1/4） $D$ 程離れている.その後, 下プリュームは上円柱壁面に 徐々に接近した。(ii)加熱開始後 40 分の状態であり,こ の時, 下プリュームが上円柱壁面に最も接近した. Fig. 4 (c)の 50 分前後における $N u$ の極小値の原因と思われる. その後, 雨者は離れていった. (iii)は加熱開始後 275 分の 状態である. 実験中，どの状態においても下プリューム は上円柱の左側を流れた。 $S / D=1 / 2$ では, 下円柱の腚 み点からの鉛直線は上円柱の接線であり，これは上円柱 壁面近傍の流れを最も加速する配置と思われる。Nu が 極小値となった時刻を除いて，下プリュームは上円柱壁 面に対してまっすぐ流入していた。また，同時に，下プ リュームが上円柱壁面に周囲低温流体を同伴していた。 これらの流れの重畳と低温流体の巻き込みのために上円 柱周りの熱伝達が促進されたものと考元られる.

Fig. 10 は $S / D=5 / 4$ に配置した場合の可視化例であ る. (i)は加熱開始後 10 分の状態である.下プリュームは まず，鉛直上昇したが，上プリュームに吸い込まれるよ うに，上プリュームに接近していった。(ii)は加熱開始後 32 分の状態である.上円柱壁面と比較的大きな吵間を保 ちつつ，上円柱壁面に沿うように流れた。(iii)は加熱開始 後 298 分の状態である. (ii)の状態とほとんど変わってい ない. その後, 400 分経過後もこの状態であった. 実験 中，下プリュームは上円柱の左側を流れ，右側を流れる ことはなかった。また，下プリュームと上円柱の距離も 大きい. そのため, 両者の干渉が小さくなり, Fig. 4(d) に示すように上円柱の状態が単一円柱加熱時の状態に近 くなったと考元られる。

\section{4 プリュームの左右のふれと熱伝達の関係}

オフセット量が小さい場合には，下プリュームが上円 柱の左右に進路を変更した。オフセット量 $0 \leqq S / D \leqq 1 /$ 4 亿おいて, 横軸に $S / D$, 縦軸に熱伝達が極小になる加 熱開始後経過時間をとった図を Fig. 11 に示す. $S / D$ が 大きくなると、熱伝達の極小值をとる時刻も変化して㧈 り, 一回目の時刻は, $S / D$ とともにわずかに遅くなる. 二回目は $S / D$ の増加とともに早く生じる傾向がある. $S / D \geq 1 / 4$ では $N u_{u}$ の極小值は 1 回しか現れなかった。 また, 図には示していないが, 加熱量が大きいほど, そ の時刻は早くなった。

\section{4. 結 言}

容器内に設置した 2 本の加熱水平円柱（垂直方向距離 は2 直径) まわりの自然対流熱伝達の, 左右に円柱をず らす（下円柱に対して上円柱を右にずらす）ことの影響

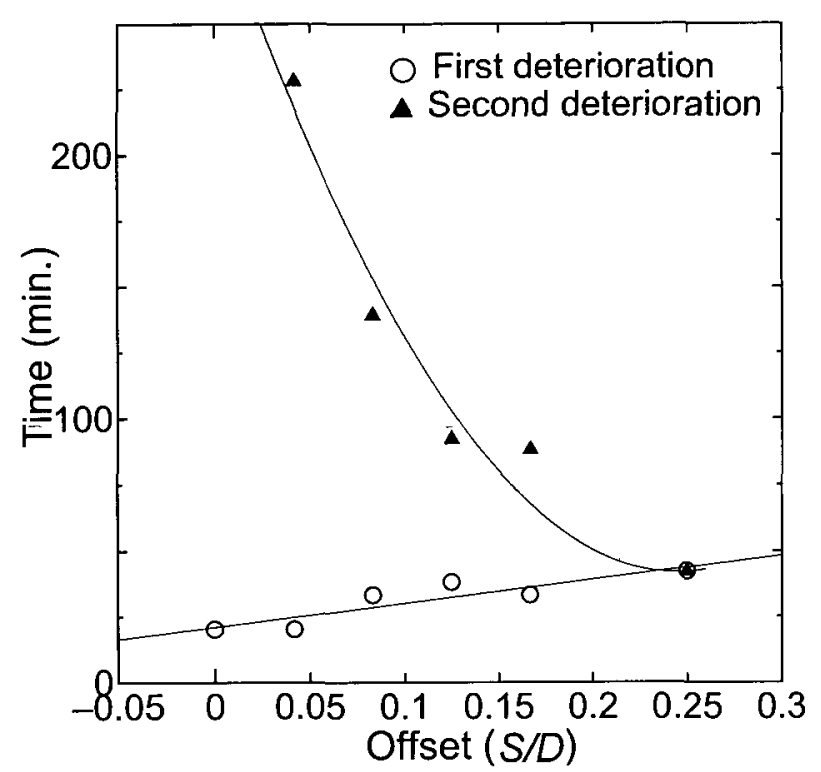

Fig. 11 Relation between $S / D$ and time when $N u_{u}$ shows sudden decrease.

を調べた。 上円柱の熱伝達の変化は下円柱プリュームと 上円柱の境界層の干涉によるものと考元られ，熱的接触 による抑制と流れの重畳による促進効果によって説明で きる。それらの効果には下円柱プリュームと上円柱の位 置関係が重要であった。熱伝達測定と感温液晶による可 視化を同時に行うことによって以下の知見が得られた。

(1) 下円柱からのプリュームが，上円柱の左右に進路 変更するかどうかは, 二本の円柱のオフセット量(左 右のズレの大きさ）に関係していた。オフセット量 が大きい場合には進路変更はなかった。

（2）二本円柱同時加熱の場合，十分長時間後には下プ リュームは上円柱の左側を通過した。この時の上円 柱のヌセルト数を上円柱単独加熱の場合と比較する と，オフセット量が大きくなるに従い，抑制，ほぼ 同等, 促進, 同等であった。

(3) オフセットの小さいときには上円柱のヌセルト数 の経時変化に顕著な增減が見られた。可視化による 観察で，この増減は下プリュームが上円柱を横切っ て進路を変えることと対応していた。

\section{参考文献}

1) Akino N., Takase K., Kameoka T., Okada Y., Proc. 3 rd. Asian Symp. on Visualization, (1994), 537.

2）稲垣 -小森, 機論, 56-530(1990), 3050.

3 ）栗山・他 3 名, 化学工学論文集, 19-10 (1993), 1074.

4 ) 機械学会編, 伝熱ハンドブック, 丸善, (1993). 